https://doi.org/10.24101/logos.2019.54

Gauta 20190820

\title{
TATJANA SOLOMONIK-PANKRAŠOVA
}

Vilniaus universitetas, Kauno fakultetas, Lietuva

Kaunas Faculty, the University of Vilnius, Lithuania

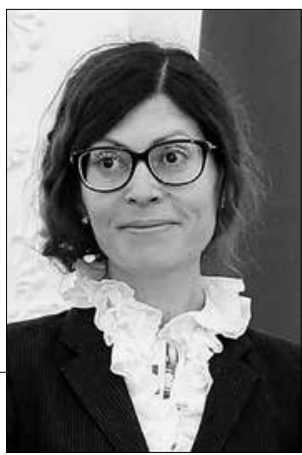

\section{THE ALLEGORY OF THE OLD ENGLISH POETIC 'JUDITH': 'FOR PAM SE CYNCG WILNAĐ PINES WLITES' ("FOR THE KING SHALL GREATLY DESIRE THY BEAUTY")}

\author{
Senovès anglų „poetinès" Juditos alegorija: 'For pam se cyncg \\ wilnað pines wlites” („Karalius trokš tavo grožio“)
}

\section{SUMMARY}

The Middle Ages believed in the existence of an invisible world of which the visible is a shadow. The statement Aliud dicitur, aliud demonstratur is applicable to the medieval propensity for symbol and allegory that opens vistas for the typological interpretation of the Old Testament characters, places and events. The Septuagint refers to the beauty of Judith as sensuous; in the Vulgata Judith is a widow whose beauty "stems from virtue". In the Old English poem Judith is described as ides alfscinu ("a damsel of elfin beauty") when she first appears before Holofernes. The present paper aims at revealing the allegory of Judith beheading Holofernes through the mystery of the Incarnation. Typological interpretation of Judith is embedded in the poetic formula ides alfscinu, which suggests the connotations of Ineffable Beauty and Light. In the poem Judith is adorned with the raiment of virtue - Faith and Virginal purity, a reflection of the Light of the First Creation.

\section{SANTRAUKA}

Straipsnyje daugiausia dèmesio skiriama senovès anglų poemoje Judita implikuojamo pamatinio viduramžių alegorijos principo Aliud dicitur, aliud demonstratur analizei. Viduramžių alegorinės tradicijos dėmesys koncentruojamas ị dievoiešką, pasaulio suvokimą veidrodžio pavidalu bei proportio ir imitatio siekį. Straipsnyje siekiama aprašyti "sielos mūšio dèl amžinojo gyvenimo" ir "sielos kovos dèl dvasinio tobulejjimo žemiškame gyvenime" alegoriją senovès anglụ hagiografinèje poemoje Judita. Darbe detaliau aptariamas 
Juditos portretas, išreikštas Skaistybės, Tikejjimo, Grožio ir Šviesos atspalviais. Septuagintoje Kristui paaukotoji Juditos našlystė, kontempliacija ir skaistybès į̌adai padeda nugalèti Izraelio tautos priešus - asirus. Senovès anglụ poemoje Juditai būdingas Nekaltumas - amžinojo gyvenimo simbolis ir tikrosios dieviškos Skaistybės (Provaizdžio) atvaizdas. Darbe detaliau aptariamas kūniškojo prado mortifikacijos motyvas, prilyginamas Juditos - Skaistybès (Pudicitia) ir Holoferno - Geismo (Sodomita Libido) dvikovai. Poetinis tekstas atveria skaitytojui dvilypes vizijas, paverčiančias mikrokosminę personifikacijos alegoriją visuotinès svarbos makrokosminiu mūšiu.

\section{MEDIEVAL AESTHETIC SENSIBILITY}

Medieval aesthetic sensibility is part of the spiritual journey to God (Rorem 1993: 79). The medieval mind perceived the beauty of the Divine Handiwork as a theophany of the Ineffable Beauty of God. In view of Umberto Eco, "the Medievals did in fact conceive of a beauty that was purely intelligible, the beauty of moral harmony and of metaphysical splendour. This is something which only the most profound and sympathetic understanding of their mentality and sensibility can restore to us nowadays" (Eco 1986: 5). In the words of Pseudo-Dionysius the Areopagite (DN IV.7): "But the Super-Essential Beautiful is called "Beauty" because of that quality which It imparts to all things severally according to their nature, and because It is the Cause of the harmony and splendour in all things, flashing forth upon them all, like light, the beautifying communications of Its originating ray" (Pseudo-Dionysius 2007: 95). Light is the principle of all Beauty not only because it is pleasurable to the sensations of sight, but also because it is through light that all the shades of splendour come into being.

In the Christian culture of the Middle Ages, the continuous search for the Unattainable God evoked especial aesthetic sensibility towards the image, mimesis or imitation of the Image, and the sublima- tion of the image (Бычков 1991: 29). The orthodox distinction between the image

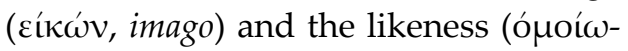
$\sigma \iota \varsigma$, similitudo) is introduced by the early Church Father, apologist Irenaeus of Lyons (ca. 130-202). On the one hand by the image Irenaeus means human soul endowed with reason and free will; on the other hand, image implies the spiritual and the carnal, the soul and the body "in close union". The (very) flesh ( $\sigma \alpha \dot{\varrho} \xi$, caro) is made in the image of God (Irenæus of Lyons (advers. Haeres. VI.1) 2018: 320). Ir. The idea that the flesh of man has become "a partaker of the divine nature" is manifest after the Incarnation of the Logos. The descent of the Logos into the world in the Image of man adheres to the Revelation of the Im-

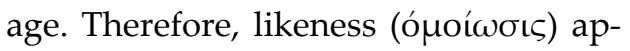
pertains to the purely spiritual ideal, cf.:

Now God shall be glorified in His handiwork, fitting it so as to be conformable to, and modelled after, His own Son. For by the hands of the Father, that is, by the Son and the Holy Spirit, man, and not [merely] a part of man, was made in the likeness of God. Now the soul and the spirit are certainly a part of the man, but certainly not the man; for the perfect man consists in the commingling and the union of the soul receiving the spirit of the Father, and the admixture of that fleshly nature which was moulded after 
the image of God. <...> For if any one take away the substance of flesh, that is, of the handiwork [of God], and understand that which is purely spiritual, such then would not be a spiritual man but would be the spirit of a man, or the Spirit of God. But when the spirit here blended with the soul is united to [God's] handiwork, the man is rendered spiritual and perfect because of the outpouring of the Spirit, and this is he who was made in the image and likeness of God. <...> Neither is the soul itself, considered apart by itself, the man; but it is the soul of a man, and part of a man. Neither is the spirit a man, for it is called the spirit, and not a man; but the commingling and union of all these constitutes the perfect man. (Ibid., p. 3)

The spiritual perfection of man ( $\varepsilon$ í$\kappa \omega \dot{v})$ adheres to his likeness of the Logos in the unity of the soul and the body that is embedded in the human nature and his likeness of God - as far as the intellectual part of the soul is concerned, for man is endowed with reason and free will.

\section{INTERPRETING MEDIEVAL POETRY: PER SPECULUM IN AENIGMATE}

Medieval poetry not only is allegorical but also didactic, ethical. All narratives promulgate emblematic figures for readers to digest, judge, eliminate or imitate. Ars poetria is mostly "the covering on some separate and separable content", verba on the one hand, res on the other. Basic to medieval aesthetic experience is ars rhetorica, the techne (in Aristotle's terms) that 'finds in each occasion the available means of persuasion' (Rhet. 1, 1) and value of judgements'. For Aristotle rhetoric embraces a theory of argumentation (inventio), a theory of style (elocutio), and a theory of composition (compositio). An active engagement with all the conditions of signification is inseparable from kairos, a doctrine of good judgement, essential to the very concept of rhetoric (Copeland 1991: 19). The idea of beauty, thus, is made distinct from the experience of beauty (Carruthers 2012: 14-15).

A peculiar feature of Old English poetry is to represent the hidden meaning behind the image; the formulaic character of Old English poetry allowed the poet to focus on the res (Clemoes 1970: 5-6) and link his ars rhetorica with the Christian mythos and the Anglo-Saxon ethos.

The Old English poem Judith ${ }^{1}$ belongs to the genre of hagiographic poetry. Being a verse paraphrase of the Old Testament Book of Judith, the poem reveals certain features that mark the genre. The equilibrium of the poetic Judith is shaped by the diction of Juvencus (Gaius Vettius Aquilinus Juvencus) and Coelius Sedulius known as Christian Vergil for his Carmen Paschale. The Judith poet imitated Juvencus' metaphoric of light (Dominus lucis) (Lapidge 2006: 14) and paid his debt to Sedulius in the allegorical and typological interpretation (Ibid., p. 17) of the Septuagint Judith.

There is a complex interplay between the allegoria productiva - the poet's creative allegory, his ars poetriaelars rhetorica and the allegoria interpretativa - traditional allegorical and typological interpretation of the Scriptures. "Allegorical interpretation (allegoresis) proposes itself as the unveiling of the Scriptural text; yet, paradoxically, such an interpretation, aiming to "save" or recuperate/re- 
consider the text is itself an act of placing a veil over the visibilia of the text, a covering of the text so that it can be hermeneutically "recovered"." (Copeland; Melville 1991: 171)

The Old Testament Judith "preserved in changeableness of nature an unchangeable beauty" (Gregory of Nyssa 1973: 76). In the poem Judith is described as ides ælfscinu (1. 14) (a damsel) "of elfin beauty") when she first appears before Holofernes, cf.:

Gefrægen ic ða Holofernus

winhatan wyrcean georne ond eallum wundrum prymlic

girwan up swæsendo; to ðām het se gumena baldor

ealle ðā yldestan ðegnas.

Hie ðæt ofstum miclum

ræfndon rondwiggende comon to ðam rican peodne

feran folces ræswan - pæt wæs py feorðan dogore

pæs ðe Iudith hyne gleaw on geðonce ides ælfscinu ærest gesohte. (11. 7b-14b)

\section{Holofernes (so heard I)}

A wine-bidding wrought well, and with wonders uncounted

Made ready a banquet; to this the boldest of captains

Summoned all his chief servants; with speed they obeyed,

The bearers of bucklers; came to the brave lord

The fighting folk-leaders. That was the fourth day

Since that Judith, judicious in mind,

The elf-bright damsel, erst had sought him. (1l. 7b-14b) (Cook 1888: 2-3)

In view of Alaric Hall, a relevant evidence for the connotations of xlf (as a generic element of the ælfscyne) is determined by its occurrence only in poetry, once in Judith and twice in Genesis A with reference to the beauty of Abraham's wife Sarah (Hall 2007: 89), a type of the Virgin Mary "under the shadow of the Old Law"2: "Ælfscyne's generic element, scyne, principally means 'beautiful' both etymologically and throughout medieval English. Like beautiful it is used in a wide variety of contexts, but almost invariably of women rather than men (except that it is often used of angels (my italics), which may afford a parallel to its association with ælf)." (Hall 2007: 92) Thus, xlfscyne denotes a quality of feminine or angelic (Intelligible) Beauty and is connected with lightness and brightness throughout the Germanic group of languages (Ibid.). The connotation of Intelligible Beauty is embedded in the text of the Vulgata (Judith 10: 4), cf.: "Cui etiam Dominus contulit splendorem: quoniam omnis ista compositio non ex libidine, sed ex virtute pendebat: et ideo Dominus hanc in illam pulchritudinem ampliavit, ut incomparabili decore omnium oculis appareret." (Migne 1845: 51) - "And the Lord also gave her more beauty: because all this dressing up did not proceed from sensuality, but from virtue: and therefore the Lord increased this her beauty, so that she appeared to all men's eyes incomparably lovely." (Douay-Rheims 1837: 457)

In her widow's weeds (fasting, sackcloth and ashes as symbolic of repentance) the Old Testament Judith ${ }^{3}$ personifies the Israelites in distress, while her adornment envisages their symbolic Exodus. Judith was canonised as sancta mulier in the Vetus Latina (Kaup 2013: 31). In the Vulgata St. Jerome is Christianising Judith 
to strengthen the typology in relation to the Virgin Mary that was concealed for Old Testament heroine. Jerome rewrites (Gera 2014: 473) the verse 16: 22 "And many desired her, but no man knew her in all days of her life since the day Manasses her husband had died and was added to his people ${ }^{4 \prime \prime}$, omitting any reference to men wooing Judith and emphasising her chastity, rather than beauty", cf.: "And chastity was joined to her virtue, so that she knew no man all the days of her life, after the death of Manasses her husband" (Douay-Rheims 1837: 462).

The opening lines of the poem celebrate Judith as an example of steady faith, cf.:

\section{Hyre ðæs Fæder on roderum}

torhtmod tiðe gefremede, pe heo ahte trumne geleafan

a to ðam Ælmihtigan. (1l. 5b-7 a)

To her the Father in Heaven,

Glorious one, granted this boon, because of her great faith

Aye in the Highest. (1l. 5b-7 a) (Cook 1888: 2-3)

In the words of Albert C. Cook, "To invest [Judith] with all the womanly attributes most reverenced by his countrymen, the poet ${ }^{5}$ endows her with virginal purity, and converts her from a Jewess of profound religious conviction to an orthodox Christian and believer in the Trinity ${ }^{6 \prime}$ (Cook 1888: xxxii).

Judith (the maiden Chastity) is a type of the Virgin Mary. The combat between the maiden Chastity (virgo Pudicitia), and Lust the Sodomite (Sodomita Libido) (Prudentius 1949: 283) is a fragment of "the fight for mansoul" portrayed in the al- legorical poem Psychomachia" ("The Fight for Mansoul"). The love for God arises from what is opposite to carnal desire dispassionate passion. Chastity, the "triumphant princess" (victrix regina 1.53 ), takes the field after Faith, the combat transcends earthly realms; the weapon of Chastity is shining (speciosis fulget in armis, 1. 41), she is "wrapped in the garment of light" (cf. Psalm 104: 2 "and art clothed with light as with garment"), allotted to human nature upon the First Creation. This "garment of light", the "genuine beauty", deprived of plurality and corporeality, was replaced by the garments of skin (passions of the flesh). For Prudentius Judith represents the curative virginity that "brought down the Word from heaven" (Ambrose (Inst. Virg. I.III.11) 2007: 365). The Light of the Incarnation created "a new flesh", so that the flesh may be both defiled and perfect, "divine", cf.:

"A hit!" cries the triumphant princess. "This shall be thy last end; for ever shall though lie prostrate; no longer shalt thou dare to cast thy deadly flames against God's man-servants; the inmost fibre of their pure heart is kindled only from the torch of Christ. Shalt thou, O troubler of mankind, have been able to resume thy strength and grow warm again with the breath of life that was extinguished in thee, after the severed head of Holofernes soaked his Assyrian chamber with his lustful blood, and the unbending Judith, spurning the lecherous captain's jewelled couch, checked his unclean passion with the sword, and woman as she was, won a famous victory over the foe with no trembling hand, maintaining my cause with boldness heaven-inspired? But perhaps a woman still fighting under the 
shade of the law had not force enough, though in so doing she prefigured our times, in which the real power has passed into earthly bodies to sever the great head by the hands of feeble agents? Well, since a virgin immaculate has borne a child, hast thou any claim remaining - since a virgin bore a child, since the day when mans' body lost its primeval nature, and power from on high created a new flesh, and a woman unwedded conceived the God Christ, who is man in virtue of his mortal mother but God along with the Father? From that day all flesh is divine, since it conceives Him and takes on the Nature of God by a covenant of partnership. For the Word made flesh has not ceased to be what it was before, that is, the Word, by attaching to itself the experience of the flesh; its majesty is not lowered by the experience of the flesh, but raises wretched men to nobler things. He remains what He ever was, though beginning to be what He was not; but we are no longer what we were, now that we are raised at our birth into a better condition. He has given to me, yet still remained for Himself; neither has God lessened what is his by taking on what is ours, but by giving his nature to ours He has lifted us to the height of his heavenly gifts. It is his gift that thou liest conquered, filthy Lust, and canst not, since Mary, violate my authority. (Prudentius 1949: 283-84)

When the soul has become dispassionate she cleaves to her desirable Beloved. For both St. Jerome and St. Ambrose Judith is the Bride who is "putting on the robes of allurement looking forward to the coming of the Bridegroom ${ }^{8}$ and seeking to please him with those memorials of marriage which are the arms of chastity":

But do you, having once for all cast away the burden of the world, sit at the Lord's feet and say: "I have found him whom my soul loves; I will hold him, I will not let him go." (Song of Songs 3, 4) And He will answer: "My dove, my undefiled is but one; she is the only one of her mother, she is the choice one of her that bare her." (Song of Songs 6, 9) Now the mother of whom this is said is the heavenly Jerusalem (Galatians 4, 26). (Jerome (Ep. XXII) 2017: 83)

Judith is allegorical typology par excellence. Judith's speech to the people of Bethulia (11. 152b-161a) bears the closest affinity with the triumphant speech of the maiden Chastity - different in verbis/ the visibilia, yet similar in res.

One of the most significant thematic parallels is achieved through the repetition of "blithe": eow ys Metod bliðe ("the Lord is blithe toward you" 1. 154) is followed by "blithe" of the dwellers of the burg (bliðe burhsittende 1. 159) that is spread "far and wide through the world" (the poetic formula geond woruld wide "throughout the wide world" 1. 156) because of the awaiting radiant wondrous victory (pæt eow ys wuldorblæd torhtlic toweard 11. 156-57) as proclaimed by the voice of the holy Judith speaking over the high wall of the city to the dwellers of Bethulia (seo halge spræc ofer heanne weall "the holy one spake over the high wall" 11. 160-61), cf.:

Ic eow secgan mag

poncwyrðe ping, pæt ge ne pyrfen leng murnan on mode: eow ys Metod bliðe, cyninga wuldor; gecyðed wearð geond woruld wide, pæt eow ys wuldorblæd

torhtlic toweard and tir gifeðe para læðða pe ge lange drugon.'

Pa wurdon bliðe burhsittende, syððan hi gehyrdon hu seo halge spræc ofer heanne weall. (1l. 152b-161a) 
Now can I tell you

A mindworthy thing, that mournful of mood

Ye no longer may be: the Lord is blithe toward you,

The Splendour of kings; it is now spread abroad,

Far and wide through the world, that victory wondrous

And radiant awaits you; renown shall be wrought

For dole and distress which long ye endured.

Then were blithe the dwellers in burg

When they had heard how the holy one spake

Over the high wall. (1l. 152b-161a)

The image of the city/Bethulia surrounded by the high wall invokes the image of the enclosure, the secret chamber, the purified heart of the Bride, the temple, the Heavenly Jerusalem, the Kingdom of God, and amplifies thematic parallels with Psychomachia through the image of the Heavenly Jerusalem and "the Son of Man coming down from high heaven and entering the city of the cleansed body" (hominis si Filius arce aetheris inlapsus purgati corporis urbem intret 11. 817-819) (Prudentius 1949: 337).

The dwellers of the burg - the Israelites - are the chosen people, the blissful souls, the pure of heart, the warriors who guard the Heavenly Jerusalem from the deadly flames of Lust the Sodomite. The pure heart can hear the divine voice -
"The voice of my beloved!" (Song of Songs, 2: 8) A life of peace - blithe - is sweeter after the psychomachia and is made enjoyable by recounting "dole and distress which long ye endured" (and tir gifeðe para læðða pe ge lange drugon 11. 157-58), cf.: "I will greatly rejoice in the Lord, my soul shall be joyful in my God; for he hath clothed me with the garments of salvation, he hath covered me with the robe of righteousness, as a bridegroom decketh himself with ornaments, and as a bride adorneth herself with her jewels." (Isaiah 61:10)

"The voice of my beloved!" (Song of Songs, 2: 8) was heard through the prophets, and "after the voice the Word came" (Gregory of Nyssa 1960: 142). In the exegesis of the poem, the divine voice is put into the mouth of Judith. Light shone at the creation by the Word's voice, and by the Word's voice the soul changed into something divine. The Light of the Incarnation that shone upon the world came from the burning bush, which outshines the stars of heaven. This symbol reveals the mystery of the Virgin Mary, who is "more honorable than the cherubim and more glorious without compare than the seraphim". The divine light came from the bush allowing the virgin shoot to wither (Gregory of Nyssa 1973: 58-59). It is dispassionate life that shall lead the soul to the knowledge of the Ineffable Light.

\section{CONCLUSIONS}

The allegory of the poetic Judith reveals the mystery of the Incarnation. Man as Imago Dei implies a unity of the spiritual and the sensuous, the soul and the body. The Light of the Incarnation removed "the tunics of skin" emblematic of the Holoferne's head and created "a new flesh" reminiscent of the First 
Creation, a state free from passions, that gives the soul kinship with the divine.

Judith's decapitation of Holofernes is emblematic of her "dispassionate passion" for God, so that in the allegorical reading she is the Bride who "grasped" her Beloved "by Faith", the one who can hear His voice and speak in His voice. Judith is lit with brilliant Light that illuminates the space of the poem suggesting

\section{Literature}

Alaric Hall. 2007. Elves in Anglo-Saxon England. Matters of Belief, Health, Gender and Identity. The Boydell Press.

Albert S. Cook. 1888. Judith. An Old English Epic Fragment. Boston: D. C. Heath \& CO., Publishers.

Deborah Levine Gera. 2014. Commentaries on Early Jewish Literature: Judith. Berlin, Boston: Walter de Gruyter.

Gervase Mathew. 1963. Byzantine Aesthetics. London: Harper \& Row Publishers.

Gregory of Nyssa. 1973. The Life of Moses. Translated by A. J. Malherbe, E. Marguson. New York: Paulist Press.

Grigorii Nysseni in Canticum Canticorum. 1960. Werner Jaeger, Hermann Langerbeck (eds.). Vol. 6. Leiden.

Irenæus of Lyons. 2018. Against Heresies. Anthony Uyl (ed.). Devoted Publishing.

Judith Kaup. 2013. The Old English Judith. A Study of Poetic Style, Theological Tradition, and AngloSaxon Christian Concepts. New York.

Macklin Smith. 1976. Prudentius' Pychomachia. Princeton: Princeton University Press.

Mary Carruthers. 2012. The Experience of Beauty in the Middle Ages. Oxford-Warburg Studies: Oxford University Press.

Michael Lapidge. 2006. Versifying the Bible in the Middle Ages, Mann J., Nolan, M. (eds.). The Text in the Community: Essays on Medieval Works, Manuscripts, Authors, and Readers: 11-41. Notre Dame: University of Notre dame Press.

Nicene and Post-Nicene Fathers. 2007. Vol. X. Philip Schaff, Rev. Henry Wallace (eds.). Ambrose Select Works and Letters. Concerning Virgins. Book I, Ch. III.11. New York. typological and thematic parallels with the Virgin Mary and Christ himself. The Israelites illuminated by the Intelligible Light become the true miles Christi, "blithe", and the pure in heart, for "everything that is illuminated becomes a light".

The deepest concern of the Judith poet might have been that his listeners shall win the "crown of Virtue" through the letter of the text.

Patrologiae latina cursus completus. 1845. S. Hieronymi Divina Bibliotheca. Series prima. Tomus XXIX. Liber Judith. Jacques-Paul Migne (ed.). Parisiis.

Paul Rorem. 1993. Pseudo-Dionysius. A Commentary on the Texts and an Introduction to Their Influence. Oxford: Oxford University Press.

Peter Clemoes.1970. Rhythm and Cosmic Order in Old English Christian Literature. Cambridge: Cambridge University Press.

Pseudo-Dionysius. 2007. The Mystical Theology and the Divine Names. Translated by C. E. Rolt. New York: Macmillan. Ch. IV (7).

Richard Marsden. 2014. The Cambridge Old English Reader. Cambridge: Cambridge University Press.

Rita Copeland, Stephen Melville. 1991. Allegory and Allegoresis, Rhetoric and Hermeneutics, Exemplaria 3 (1): 159-187. <https://doi.org/10.1179/ exm.1991.3.1.159> [Accessed on 201906 20].

Rita Copeland. 1991. Rhetoric, Hermeneutics and Translation in the Middle Ages. Academic Traditions and Vernacular Texts. Cambridge: Cambridge University Press.

St. Jerome. 2017. The Letters. Translated by H. W. Freemantle, G. Lewis and W. G. Martley. D. P. Curtin (ed.). Dalcassian Publishing.

The Banquet. 1917. Logos 6. Section 3. G. N. Bonwetsch (ed.). Leipzig, quoted in Gervase Mathew. 1963. Byzantine Aesthetics. London: Harper \& Row Publishers: 41.

The Holy Bible, the Douay and Rheims translation. 1837. The Book of Judith. Richard Coyne \& Keating and Brown.

The Loeb Classical Library. Prudentius. 1941. Psychomachia. Jeffrey Henderson, G. P. Goold (eds.). With an English translation by H. J. Thomson. Vol. I. LCL 387. Harvard University Press. 
Umberto Eco. 1986. Art and Beauty in the Middle Ages. Translated by H. Bredin. Yale University Press.

\section{Endnotes}

1 The poem Judith is kept in 'the Beowulf-manuscript' (London, British Library, Cotton Vitellius A. XV, fols. 202r-209v), which was written out between 1000 and 1010 by two scribes. The Beowulf-manuscript was damaged in a fire in Sir Robert Cotton's library in London in 1731 (Marsden 2014: 270-271).

2 As Isaac is a type of Christ, so Sarah is a type of the Virgin Mary and her virginal conception. Both Isaac and Christ are promised children; both Sarah and Mary are barren women who conceive through the power of God. Sarah is a figure of still a more heroic faith of the Virgin Mary, Association of Hebrew Catholics Lecture Series. The Mystery of Israel and the Church. Spring 2013 Series 11 Typology of Abraham, Sarah, and Isaac, Gen. 12-22. <https://www.hebrewcatholic.net/ wp-content/uploads/2013/06/11.07TypologyofA brahamSarahandIsaac.pdf $>$ [accessed 201906 20].

3 ,The Septuagint Judith is a translation text, but there is no extant trace of an early Hebrew text of Judith, not even a single fragment. Judith is undoubtedly a Jewish work, Judith herself is portrayed as an ideal Jewish heroine, as her very name Yehudit, indicates." (Gera, 2014: 11)

4 Septuaginta: Vetus Testamentum Graecum. 1979. Auctoritate Academiae Scientarium Gottingensis editum VIII.4. Iudith. Göttingen: Vendenhoeck \& Ruprecht. <http://ccat.sas.upenn.edu/ nets/edition/18-ioudith-nets.pdf $>$ [Accessed on 201906 25].

5 Some scholars attributed the poem Judith to the hand of the first Anglo-Saxon poet Cædmon (flourished 658-680), whose name appears on the pages of Historia Ecclesiastica Gentis Anglorum by the Venerable Bede (ca. 673-735), whilst others believe that Judith might be composed either by Cynewulf (ca. 770-840) or one of his disciples (Cook, 1888: xiv-xv). The source of inspiration for the Judith poet could be traced to a commentary on the Book of Judith by the learned
Бычков, В. В. 1991. Малая история Византийской эстетики. Киев.

Rabanus Maurus, one of the first theologians and scholars of his epoch; the commentary is dedicated to Judith, wife of Louis the Pious and mother of Charles the Bold (Ibid., p. xxiv).

6 The Ruler of Heaven By name she besought, the Saviour of all, Who dwell in the world, and spake these words: O God of beginnings, and Giver of comfort, The Almighty's Son, I seek for thy mercy; Be now benignant to me in need, O Power of the Trinity (1l. 79b-85a) (Ibid., p. 9).

7 Psychomachia by Aurelius Clemens Prudentius (ca. 348-405) "is the major source of a rich allegorical tradition extending through the Middle Ages and into the eighteenth century. In Psychomachia, the mere presence of the Old Testament characters mentioned by is secondary in relation to this dynamic New Testament typology" (Smith 1976: 6).

8 "The Apostle could apply directly to Christ all that was said of Adam. It is in excellent accord with this that the Church has been formed from His flesh and bone. For it was for her sake that the Logos left His heavenly father and came down to earth in order to cling to His Spouse and slept in the ecstasy of His passion ... cleansing her with the laver for that blessed spiritual seed which sows and plants; and like a woman the Church conceives of this seed and forms it." (Mathew 1963: 41) Methodios wrote of the Ekklesia as the Woman of the Apocalypse, cf.: "She gleams in pure, unsullied and abiding beauty, emulating the brilliance of the lights. She is clothed in pure light for her garment. Her head is adorned with shining stars instead of jewels. Light is for her what closing is for us. She uses the stars as we do gold and brilliant gems." The Banquet. 1917. Logos 6. Section 3. Ed. G. N. Bonwetsch. Leipzig, quoted in Gervase Mathew. 1963. Byzantine Aesthetics. London: Harper \& Row Publishers: 41. 